\title{
Novas Cultivares \\ BRS Guamirim: cultivar de trigo da classe pão, precoce e de baixa estatura
}

\author{
Pedro Luiz Scheeren ${ }^{(1)}$, Eduardo Caierão(1), Márcio Só e Silva ${ }^{(1)}$, Leo de Jesus Antunes Del Duca(1), \\ Alfredo do Nascimento Junior ${ }^{(1)}$, Aroldo Linhares ${ }^{(1)}$ e Luiz Eichelberger ${ }^{(1)}$
}

\begin{abstract}
(1)Embrapa Trigo, Rod. BR 285, Km 294, Caixa Postal 451, CEP 99001-970 Passo Fundo, RS, Brasil. E-mail: scheeren@cnpt.embrapa.br, caierao@cnpt.embrapa.br, soesilva@cnpt.embrapa.br, delduca@cnpt.embrapa.br, alfredo@cnpt.embrapa.br, aroldo@cnpt.embrapa.br, luizei@cnpt.embrapa.br
\end{abstract}

Resumo - A cultivar de trigo BRS Guamirim foi desenvolvida pela Embrapa e resultou de um cruzamento entre os genitores Embrapa 27/Buck Nandu e PF 93159. Possui ciclo precoce, baixa estatura de planta e intenso afilhamento. Apresenta equilibrada reação às principais moléstias do trigo, pertence à classe pão e demonstra adaptabilidade às diferentes regiões tritícolas do país, com estabilidade de produção. Seu potencial de rendimento é superior a $5 \mathrm{tha}^{-1}$.

\section{BRS Guamirim: bread wheat cultivar, early cycle and short stature}

\begin{abstract}
Wheat cultivar BRS Guamirim was developed by Embrapa and resulted from a cross among Embrapa 27/Buck Nandu and PF 93159. BRS Guamirim has early cycle, short plant stature and high tillering. It shows equilibrate behaviour to mainly wheat deseases, belongs to bread class and is adapted to different wheat regions, showing production stability. Its grain yield potential is higher than $5 \mathrm{t} \mathrm{ha}^{-1}$.
\end{abstract}

\section{Introdução}

A pesquisa agropecuária nacional tem contribuído significativamente para o aumento da produtividade e para a melhora da qualidade do trigo brasileiro.

O melhoramento genético de trigo no Brasil começou em 1919, com a criação, pelo Ministério da Agricultura, de estações experimentais em Alfredo Chaves (hoje Veranópolis, RS) e em Ponta Grossa, PR. Naquela época, o trabalho de melhoramento era basicamente direcionado para a seleção de plantas em progênies oriundas de coletas de sementes de genótipos utilizados pelos colonos. Somente em 1925 foram realizados os primeiros cruzamentos artificiais em trigo. Como conseqüência desses primeiros trabalhos, foi lançada para cultivo, em 1940, a cultivar Frontana (Beckman, 1965), considerada até hoje a maior contribuição do melhoramento genético nacional para o trigo no mundo, principalmente pela resistência da planta adulta à ferrugem da folha, resistência à debulha e à germinação na espiga (Sousa, 2004).

A década de 70 foi propícia ao desenvolvimento do melhoramento genético de trigo no Brasil, com a criação de vários centros de pesquisa na Região Sul, estatais e privados, com destaque para o Centro Nacional de Pesquisa de Trigo (Embrapa Trigo, em Passo Fundo, RS). Com isso, expandiu-se a área de cultivo deste cereal e surgiram diversas cooperativas. A criação de comissões técnicas de pesquisa foi importante na sistematização e na racionalização do trabalho de pesquisa.

A partir de 1997, foram estabelecidas as leis e normas sobre o registro e a proteção de cultivares de trigo. Por essa nova sistemática, a decisão de se lançar uma nova cultivar passou a ser de total responsabilidade do detentor do material, não sendo necessária a aprovação prévia da comissão de pesquisa.

A maioria dos programas de melhoramento no país tem por objetivo: obter cultivares tolerantes à acidez do solo; buscar genótipos com genes de resistência às principais doenças do trigo; melhorar o tipo agronômico, o potencial produtivo e a qualidade tecnológica. Atualmente, esses programas de melhoramento buscam a criação de cultivares mais equilibradas, em relação ao desempenho agronômico e industrial, para aumentar a vida útil de lavoura, por meio da incorporação de genes de resistência durável às principais moléstias biotróficas 
do cereal. Porém, o grande desafio da triticultura nacional é a expansão do cereal para outras regiões brasileiras, como os Cerrados (Sousa, 2004).

O sucesso do melhoramento genético do trigo no país tem sido obtido tanto pelo método de cruzamentos quanto pelo de introduções, especialmente de cultivares mexicanas. Poucos resultados foram obtidos por mutação. Como prova da contribuição genética dos programas de melhoramento de trigo, para a cadeia produtiva deste cereal no Brasil, de 1922 até 2003, foram recomendadas 429 cultivares (Sousa, 2004). Somente no Rio Grande do Sul, por exemplo, estavam recomendadas para cultivo, no ano de 2004, mais de 50 cultivares de diferentes obtentores (Reunião da Comissão Sul-Brasileira de Pesquisa de Trigo, 2004).

O programa de melhoramento genético de trigo da Embrapa tem como meta disponibilizar cultivares com desempenho agronômico competitivo e aptas aos diferentes segmentos da indústria moageira. Este trabalho teve como objetivo divulgar para a sociedade científica as características da nova cultivar de trigo BRS Guamirim.

\section{Características da cultivar}

BRS Guamirim resultou do cruzamento entre o genitor materno (Embrapa 27/Buck Nandu) e o genitor paterno PF 93159 (BR 23//CEP 19/PF 85490), realizado na Embrapa Trigo, em Passo Fundo, RS, em 1994. A geração $F_{1}$ foi conduzida em telado, no verão de 1995. Sobre as plantas em geração $\mathrm{F}_{2}, \mathrm{~F}_{3}, \mathrm{~F}_{4}, \mathrm{~F}_{6}$ e $\mathrm{F}_{8}$, no inverno e no campo, e nas gerações $F_{5}$ e $F_{7}$, no verão e em telado, foi realizada a seleção com base no tipo agronômico de planta e na resistência às principais moléstias do trigo, por meio de inoculações artificiais, com o método genealógico. Em todas as gerações, após a trilha das plantas selecionadas, realizou-se a seleção de grãos. Em 1999, uma das linhas selecionadas foi semeada em campo, em geração $\mathrm{F}_{8}$, que apresentou uniformidade e foi colhida sob a denominação de linhagem PF 990407. Em 2000, a linhagem foi avaliada em ensaio preliminar local, em 2001 no ensaio preliminar em rede, e nos anos de 2002 a 2005 no ensaio para determinação do seu valor de cultivo e uso (VCU).

Durante os anos em que fez parte do ensaio para determinação do VCU, a cultivar BRS Guamirim apresentou excelente desempenho para produtividade de grãos, e totalizou 3\% de superioridade em relação à média das testemunhas utilizadas para comparação, na média dos anos de avaliação. Particularmente nos anos de 2003 e 2004, apresentou média de 3.824 e $3.640 \mathrm{~kg} \mathrm{ha}^{-1}$, respectivamente 1 e $10 \%$ acima da média das testemunhas (Tabela 1).

BRS Guamirim caracteriza-se por apresentar ampla adaptação, com bom desempenho produtivo nos diferentes estados, desde o Rio Grande do Sul até São Paulo e, nesse período de ensaios, seu melhor rendimento médio de grãos foi alcançado no Paraná, no ano de 2003, com $5.352 \mathrm{~kg} \mathrm{ha}^{-1}$ (Tabela 1). O peso do hectolitro $(\mathrm{PH})$ médio da cultivar BRS Guamirim, ao longo dos anos de avaliação, nos diferentes estados, foi de $75,4 \mathrm{~kg}$, valor praticamente igual ao obtido pela média das testemunhas $(74,8 \mathrm{~kg})$. O melhor valor médio para esta variável foi obtido no Paraná, em 2004, com 78,9 kg (Tabela 2). Em razão do seu desempenho nestas características e das tecnologias de cultivo atualmente disponíveis aos produtores, esta cultivar foi registrada para comercialização em todas as regiões tritícolas do Brasil.

A cultivar BRS Guamirim pertence à classe pão e pode ser utilizada na fabricação de massas alimentícias, bolachas tipo crackers, pão industrial e mescla com trigos brandos para fins de panificação. Nos anos em que fez parte do ensaio de VCU, apresentou força de glúten média de $249.10^{-4} \mathrm{~J}$, com variação observada de $114.10^{-4} \mathrm{a} 375 \cdot 10^{-4} \mathrm{~J}$. Para o Estado do Rio Grande do Sul, a cultivar apresentou valores médios de $232.10^{-4} \mathrm{~J}$. Análises laboratoriais indicaram a presença das bandas n, $2+12$ e $7+8$ para as gluteninas. Dados obtidos experimentalmente, com utilização de moinho Brabender, indicaram uma variação no rendimento de farinha de 51,4 a $64 \%$.

BRS Guamirim é um trigo de primavera e possui estatura baixa, com média de $78 \mathrm{~cm}$ nos anos de avaliação em ensaios. Apresenta ciclo precoce, tanto no período da emergência ao espigamento (média de 74 dias variação de 70 a 77, em Passo Fundo), quanto da emergência à maturação (média de 125 dias - variação de 123 a 127, em Passo Fundo). Com relação aos principais estresses abióticos do trigo, a cultivar BRS Guamirim caracteriza-se por ser moderadamente resistente à debulha natural, à germinação na espiga, ao crestamento e ao acamamento e é, em fase vegetativa, moderadamente suscetível à geada.

Para as principais moléstias da cultura, a cultivar tem reação equilibrada; é moderadamente resistente à ferrugem da folha (Puccinia triticina), ao oídio (Blumeria graminis) e às manchas-foliares; é 
moderadamente suscetível à giberela (Gibberella zeae) e suscetível ao vírus-do-mosaico. Especificamente com relação à ferrugem da folha (notas em casa de vegetação), apresentou reação de suscetibilidade para as raças $\mathrm{B}_{37}$ e $\mathrm{B}_{50} \mathrm{e}$, para as demais, apresentou reação de resistência $\left(B_{27}, B_{29}, B_{32}, B_{33}, B_{35}, B_{38}, B_{39}, B_{40}, B_{41}\right.$, $\mathrm{B}_{43}, \mathrm{~B}_{44}, \mathrm{~B}_{45}, \mathrm{~B}_{48}, \mathrm{~B}_{49}, \mathrm{~B}_{51}$ e $\mathrm{B}_{52}$ ).

BRS Guamirim é descrita como uma cultivar com folha bandeira predominantemente ereta ( $85 \%$ das situações), e aurículas incolores (82,5\% situações).
Possui espiga fusiforme, com coloração clara na maturação e presença de aristas. O grão característico é vermelho e ovalado.

BRS Guamirim está registrada no Ministério da Agricultura, Pecuária e Abastecimento (MAPA) sob o número 20038. A semente genética da cultivar é de responsabilidade da Embrapa Trigo, a básica $\left(S_{1}\right)$ é da Embrapa Transferência de Tecnologia e a Certificada $\left(\mathrm{C}_{1}\right)$ é da Fundação Pró-sementes de Apoio à Pesquisa.

Tabela 1. Rendimento de grãos $\left(\mathrm{kg} \mathrm{ha}^{-1}\right)$ da cultivar BRS Guamirim, em comparação com as diferentes testemunhas, nos anos do ensaio para determinação do valor de cultivo e uso (VCU), nos diferentes estados em que foi avaliada.

\begin{tabular}{|c|c|c|c|c|c|}
\hline Local & Genótipo & 2002 & 2003 & 2004 & Média \\
\hline \multirow[t]{2}{*}{ Rio Grande do Sul } & BRS Guamirim & 3.268 & 4.882 & 4.006 & 4.052 \\
\hline & Média de Ônix, Rubi, BRS 49 & 3.367 & 4.802 & 3.906 & 4.025 \\
\hline \multicolumn{2}{|c|}{ Porcentagem em relação às testemunhas } & 97 & 102 & 103 & 101 \\
\hline \multirow[t]{2}{*}{ Santa Catarina } & BRS Guamirim & 2.698 & 3.806 & 4.350 & 3.618 \\
\hline & Ônix & 2.877 & 4.726 & 3.618 & 3.740 \\
\hline \multicolumn{2}{|c|}{ Porcentagem em relação à testemunha } & 94 & 81 & 120 & 97 \\
\hline \multirow[t]{2}{*}{ Paraná } & BRS Guamirim & 2.730 & 5.352 & 4.255 & 4.112 \\
\hline & Ônix & 2.769 & 4.389 & 3.655 & 3.604 \\
\hline \multicolumn{2}{|c|}{ Porcentagem em relação à testemunha } & 99 & 122 & 116 & 114 \\
\hline \multirow[t]{2}{*}{ São Paulo } & BRS Guamirim & 1.621 & 2.793 & 3.188 & 2.534 \\
\hline & Ônix & 1.600 & 2.427 & 2.769 & 2.265 \\
\hline \multicolumn{2}{|c|}{ Porcentagem em relação à testemunha } & 101 & 115 & 115 & 112 \\
\hline \multirow[t]{2}{*}{ Mato Grosso do Sul } & BRS Guamirim & 3.577 & 2.288 & 2.403 & 2.756 \\
\hline & BR 18 & 3.577 & 2.543 & 2.651 & 2.924 \\
\hline \multicolumn{2}{|c|}{ Porcentagem em relação à testemunha } & 100 & 90 & 91 & 94 \\
\hline \multirow[t]{2}{*}{ Brasil } & BRS Guamirim & 2.779 & 3.824 & 3.640 & 3.414 \\
\hline & Média das testemunhas & 2.838 & 3.777 & 3.320 & 3.312 \\
\hline \multicolumn{2}{|c|}{ Porcentagem em relação às testemunhas } & 98 & 101 & 110 & 103 \\
\hline
\end{tabular}

Tabela 2. Peso do hectolitro $\left(\mathrm{kg} 100 \mathrm{~L}^{-1}\right)$ da cultivar BRS Guamirim, em comparação com as diferentes testemunhas, conforme o estado, nos anos do ensaio para determinação do valor de cultivo e uso (VCU), nos diferentes estados em que foi avaliada.

\begin{tabular}{|c|c|c|c|c|c|}
\hline Local & Genótipo & 2002 & 2003 & 2004 & Média \\
\hline \multirow[t]{2}{*}{ Rio Grande do Sul } & BRS Guamirim & 69,2 & 75,4 & 77,5 & 74,0 \\
\hline & Média de Ônix, Rubi, BRS 49 & 72,2 & 75,6 & 76,3 & 74,7 \\
\hline \multicolumn{2}{|c|}{ Porcentagem em relação às testemunhas } & 95,8 & 99,7 & 101,6 & 99,1 \\
\hline \multirow[t]{2}{*}{ Santa Catarina } & BRS Guamirim & 77,9 & 76,3 & 74,2 & 76,1 \\
\hline & Ônix & 74,2 & 76,7 & 72,3 & 74,4 \\
\hline \multicolumn{2}{|c|}{ Porcentagem em relação à testemunha } & 105,0 & 99,5 & 102,6 & 102,3 \\
\hline \multirow[t]{2}{*}{ Paraná } & BRS Guamirim & 73,8 & 76,7 & 78,9 & 76,0 \\
\hline & Ônix & 69,6 & 75,7 & 79,0 & 73,8 \\
\hline \multicolumn{2}{|c|}{ Porcentagem em relação à testemunha } & 106,0 & 103,4 & 99,9 & 103,0 \\
\hline \multirow[t]{2}{*}{ São Paulo } & BRS Guamirim & - & - & 74,2 & 74,2 \\
\hline & Ônix & - & - & 73,3 & 73,3 \\
\hline \multicolumn{2}{|c|}{ Porcentagem em relação à testemunha } & - & - & 101,2 & 101,2 \\
\hline \multirow[t]{2}{*}{ Mato Grosso do Sul } & BRS Guamirim & 76,9 & 75,4 & 77,2 & 76,5 \\
\hline & BR 18 & 80,3 & 78,0 & 75,0 & 77,8 \\
\hline \multicolumn{2}{|c|}{ Porcentagem em relação à testemunha } & 95,8 & 96,7 & 102,9 & 98,4 \\
\hline \multirow[t]{2}{*}{ Brasil } & BRS Guamirim & 74,5 & 75,6 & 76,4 & 75,4 \\
\hline & Média das testemunhas & 74,1 & 75,8 & 75,2 & 74,8 \\
\hline \multicolumn{2}{|c|}{ Porcentagem em relação às testemunhas } & 100,5 & 99,8 & 101,6 & 100,8 \\
\hline
\end{tabular}




\section{Referências}

BECKMAN, I. Retrospecto da obra fitotécnica de um geneticista. Bagé: Estação Experimental de Bagé, 1965. 10p.

REUNIÃO DA COMISSÃO SUL-BRASILEIRA DE PESQUISA DE TRIGO, 36., 2004, Passo Fundo. Indicações técnicas da
Comissão Sul-Brasileira de Pesquisa de Trigo: 2004: inclui indicações técnicas para a cultura de triticale. Passo Fundo: Embrapa Trigo, 2004. 152p.

SOUSA, C.N.A. Cultivares de trigo indicadas para cultivo no Brasil e instituições criadoras. Passo Fundo: Embrapa Trigo, 2004. $138 \mathrm{p}$.

Recebido em 13 de março de 2006 e aprovado em 27 de outubro de 2006 